\title{
The International
}

and

\section{Comparative Law Quarterly}

\section{VOLUME 27}

1978

William S. Hein \& Co., Inc.

Buffalo, New York

2003 
Q British Institute of International and Comparative Law 1978.

Published by Oxford University Press.

All rights reserved

This book has been digitally archived, to maintain the quality of the original work for future generations of legal researchers, by William S. Hein \& Co., Inc.

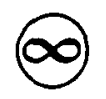

This volume is printed on acid-free paper by William S. Hein \& Co., Inc. 


\section{The International and Comparative Law Quarterly}

BOARD OF EDITORS

General Editor

K. R. Simmonds

Assistant General Editor

.TOM HARPER

P. B. Carter

A. K. R. KIRALFY

Norman S. MARSH, Q.c.

Contributions to the International and Comparative Law Quarterly express the views of their authors and not necessarily the views of the Editorial Boord or of the British Institule of International and Comparative Law. 


\section{The British Institute of International and Cómparative Law COUNCIL: OF MANAGEMENT}

Chairman: The Rt. Hon. Lord Denning, M.R.

Vice-Chairman: M. E. Bathurst, C.M.G., C.B.E., D.C.L., LL.D., Q.C.

Professor Sir Norman Anderson, O.B.E., D.D., LL.D., P.B.A., Q.C.

A. E. Anton, C.B.E., P.B.A.

Professor A. L. Diamond

Sir Vincent Evans, G.C.M.G.? M.B.B., Q.C.

Sir Gerald Fitzmaurice, G.C.M.G. Q.C.

N. Fox Bassett

Professor R. H. Graveson, C.B.E., L.D.D., Q.C.

Professor C. J. Hamson, Q.C.

Master I. H. Jacob. Q.c.

Professor R. Y. Jennings, LL.D., Q.C.

The Hon. Mr. Justice Kerr

* The Rt. Hon. Chief Justice

Bora Laskin
* Professor R. St. J. Macdonald. Q.C.

Sir James McPetrie, K.C.M.G., O.B.E.

F. A. Mann, LL.D., Dr.Jur., F.B.A.

Normàn S. Marsh, C.B.E., Q.C.

Andrew Martin, Q.C.

Thè Rt: Hon. Sir Robert Megarry, P.C., LL.D., P.B.A.

The Rt. Hon. Lord Scarman. O.B.B.

The Rt. Hon. Lord Shawcross, G.B.E., Q.C.

Sir Ian Sinclair, K.C.M.G.

Professor Sir Francis Vallat, K.C.M.G., Q.C.

Professor Sir Humphrey Waldock. C.M.G., O.D.E., D.C.L., Q.C.

E. H. Wall, T.D.

G. G. Williams

* Commonwealth Member

ADVISORY BOARD

Public International Law Section

Chairman: Sir Gerald FitzmaUrice, G.C.M.G., Q.C.

Private International Law Section

Chairman: The RT. HoN. LORD SCARMan, O.B.E.

Comparative Law Section

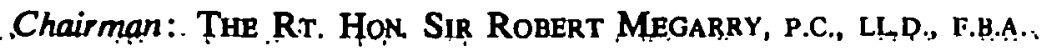

HON. DIRECTOR

Professior K. R. SIMMONDS 


\section{TABLE .OF . CONTENTS:}

(An alphabetical Index of Contributors, a Subject Index, an Index of Cases Noted and an Index of Book Reviews and Books Received, will be found at pp. 1 et seq.)

\section{ARTICLES}

PAGE

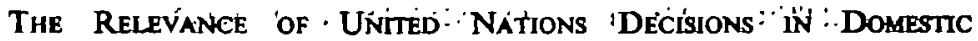
LITIOATION Christoph H. Schreuer

Recodinition óm Revolutionary Authorities: Law and Practicb. $\because \because$ of States i ... A. C. Bundi

THe European SPace Aogncy , Rüdigér Freiheir von Preuschen : 46

The Management of Federal Petroleum Resources in the Unted : :

'... States: . . . Robert B. Krueger

The Law-Creative Role of A ppeliate Courts in the Commonwealth Jack A. Hiller 85

Social Securty and Family 'LA'w'in Australia' · Ronald Sackillle'

The Extraterritorial Cruminal Jurisdiction of English Courts Juliàn D. M: Lew $\cdot 168$

The Coniractual Capactty of Minors in English and French

$\because$ LiAw of Empló̀ment

The Eúropenan Court añd the Brussels Convention on JuRisdiction. AND" JUDGMENTS

Retention 'óf'Tŕmie tó Sale of Gódos In Európean Law'

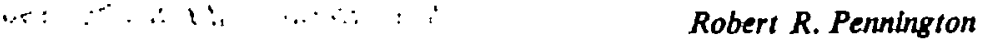

The Law of ToRts and Codification In IsRaEL ' . . G. Tedeschi

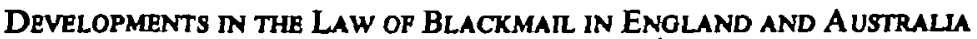

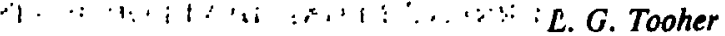

Intoxication and Crime: A Comparative Approach

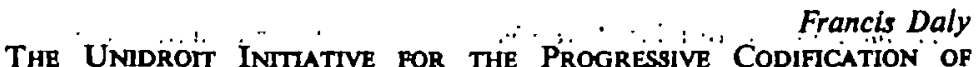
InTERnational Trade Law 'M. J. Bónell

COMPany Law, aNd THE Non-Executtve Drepector-The USA AND BRT́tain COMPared

A. J. Boyle 487

Lioal Structures of Small Bustnesses in France and Enoland COMPARED

R. R. Drury 510

Two-Tier LAw-A New Approach to Law Makno Alan Watson

'The Chanóng Legal Regime of AIr and Outer Spacé

D. Goedhuis

General Pronciples of Law and the U.N. Covenanit on Civil añ Polmical Rughts. Natalie, K. Hevener and Sieven A. Mosher

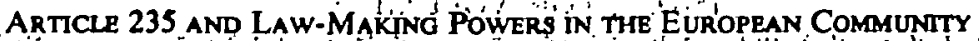

Avo E Schivartz" 614

Ö́nerLappino European Laws

F.E. Dowhick 629

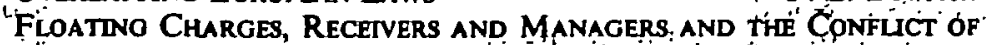
LAWs

'Läwrènce' Cóllins "69'1

International Safeguards agadnst the Diversion of Nuclear MATERIALS TO NON-PEACEFUL USES

Lyn Parker 711

INTERnational Boundaries-A * Case Study of the GuYanaSURNAM BOUNDARY

P. K. Menon 738 
Multinational ENTERPRises AND the ExTRATERrTtorLAL APPLICATION OF LABOUR LAW

Felice Morgenstern and Blaise Knapp 769

Development Value aNd the Law-The UNTTED Kingdom and AUSTRALIAN EXPERIENCE Alan Fogg 794

The Fammy Court of Australla and Informality In Court Procedoure Jolin Wade 820

moral Damage in Germany

P. R. Handford

Soviet Policy of Separatino Famires and the Rloht to Emiorate Fred Mehl and Sandra E. Rapoport

\section{SHORTER ARTICLES, COMMENTS AND NOTES}

The East Timor Dispute

Soviet Fishery Jurisdiction

Foreign Policy and Judicial Discretion

The Uniform Interpretation of International Conventions

R. J. C. Munday

Security Council Resolutions and Non-Members of the United Nations

Kelvin Widdows

The United Nations and Civil and Political Rights in Chile

Paul D. Elliont

W. E. Butler 442

X. 446

Unfair Contract Terms Act 1977 and the Conflict of Laws

Marc Bossuyt 462

F. A. Mann 661

Corporal Punishment in the Isle of Man

Graham Zellick 665

The Position of Head of State in an Independent Papua New Guinea

D. Chalmers

Unemployment Benefit in U.K. and Federal Republic of Germany 672 Ireland v. Unlted Kingdom K. C. Horton and I. Snaith David Bonner.

\section{CURRENT LEGAL DEVELOPMENTS}

Insider Trading: Great Britain; Sovereign Immunily: United States and United Kingdom

Lomd Convention: Renegotiation; South-West Africa: Namibia and Walvis Bay

BOOK REVIEWS $255,472,685,890$

BOOKS RECEIVED 479,688

INDEX FOR VOLUME 27

Contributors of Articles, Shorter Articles, Comments and Notes 